\title{
PENGUKURAN KUALITAS DAN MUKA AIR TANAH DI SEKITAR PT. BIO NUSANTARA TEKNOLOGI UNTUK MENDUKUNG PROSES PEMBELAJARAN FISIKA
}

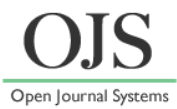

\author{
Dwi Alfina Septianingsih ${ }^{1} *$, M. Lutfi Firdaus ${ }^{1}$, M. Farid ${ }^{2}$ \\ ${ }^{1,2}$ Pascasarjana Pendidikan IPA FKIP Universitas Bengkulu, Bengkulu \\ ${ }^{2}$ Jurusan Fisika FMIPA Universitas Bengkulu, Bengkulu \\ *finafisika@gmail.com
}

\begin{abstract}
ABSTRAK
Penelitian ini bertujuan untuk mengetahui potensi air tanah di sekitar perkebunan sawit di Desa Pondok Kelapa-Bengkulu yang dilakukan dengan menggunakan resistivity-meter metode geolistrik, konfigurasi elektroda Wenner. Data pengukuran muka air tanah dan hasil kualitas air diperoleh pada 4 lokasi penelitian. Interpretasi kurva resistivitas dengan Res2dinv menunjukkan bahwa daerah Pondok Kelapa masih memiliki potensi air tanah dengan jarak 0,5 m. Keempat lokasi diantaranya: (1) pada rata-rata kedalaman $1,967 \mathrm{~m}$ dengan $\mathrm{pH}$, besi $0,0021 \mathrm{mg} / \mathrm{L}$ dan kekeruhan $54,16 \mathrm{NTU}$; (2) pada rata-rata kedalaman 2,935 m dengan $\mathrm{pH}$ 6, besi $0,0022 \mathrm{mg} / \mathrm{L}$ dan kekeruhan 37,12 NTU; (3) pada rata-rata kedalaman 2,240 m dengan $\mathrm{pH} 5,8$, besi $0,0021 \mathrm{mg} / \mathrm{L}$ dan kekeruhan 35,65 NTU; dan (4)pada rata-rata kedalaman 2,678 m dengan $\mathrm{pH} 5,7$, kandungan besi $0,0011 \mathrm{mg} / \mathrm{L}$ dan kekeruhan 19,02 NTU. Hasil penelitian menyimpulkan bahwa terdapat kecenderungan hubungan terbalik antara kualitas air dan muka air tanah dari segi kekeruhan. Hasil penelitian ditampilkan sebagai penunjang proses pembelajaran Fisika yakni pengembangan LKPD berbasis service learning materi Hukum Ohm penerapan pengukuran geolistrik yang berorientasi pada pengembangan reflective thinking dengan desain ADDIE (Analisys, Design, Development, Implementation, and Evaluation). Kemampuan hasil belajar 21 siswa SMK kelas X-ATP (Agribisnis Tanaman Perkebunan) didapat dengan peningkatan hasil $\mathrm{N}_{\text {gain }}$ antara nilai pretest dan posttest sebesar 0,66 yakni berada dalam kategori sedang.
\end{abstract}

Kata Kunci: Kualitas air; muka air tanah; PT Bio Nusantara Teknologi; pembelajaran fisika.

\section{PENDAHULUAN}

Air adalah bahan alam yang memegang peranan sangat penting untuk kehidupan umat manusia, hewan dan tanaman. Purnama et al (2007) menyebutkan, dari segi kuantitas air tanah akan mengalami penurunan kemampuan penyediaan apabila jumlah yang digunakan melebihi ketersediaannya.

Dari segi kualitas air memiliki syarat tidak berasa, tidak berbau, jumlah zat padat terlarut, warna, kekeruhan, serta suhu tidak melebihi batas syarat, sedangkan kualitas kimia berarti kandungan unsur-unsur tertentu baik organik maupun anorganik dalam air tidak kurang dari batas minimum atau tidak melebihi batas maksimum.

Perkembangan perkebunan kelapa sawit yang sangat pesat serta banyaknya kebutuhan air yang diserap, perlu menjadi perhatian sebagai suatu isu lingkungan terutama yang terkait dengan terganggunya tata kelola air.
Perkebunan kelapa sawit yang sifatnya monokultur dinilai sebagai penyebab berkurangnya ketersediaan air tanah dan dapat menurunkan muka air tanah (Sandhyavitri, 2014).

Pada area pertanaman kelapa sawit, pola penurunan muka air tanah terjadi pada periode April-September. Kajian potensi air tanah dapat diketahui dengan melakukan pengukuran titiktitik dugaan menggunakan alat resistivitymeter dengan metode geolistrik.

Metode geolistrik merupakan salah satu metode survai yang menggunakan sistem induksi arus listrik untuk mengetahui resistivitas batuan bawah permukaan. Melalui pengukuran pendugaan geolistrik akan diketahui sifat-sifat aliran listrik pada batuan di bawah permukaan bumi. Dalam metode geolistrik terdapat beberapa macam konfigurasi elektroda yaitu: Wenner, Schlumberger, Wenner-Schlumberger, Dipole-dipole dsb. 
Pengukuran metode geolistrik ini dilakukan dengan cara menginjeksikan arus listrik melalui dua buah elektroda arus dan mengukur hasil perbedaan voltase pada dua elektroda potensial yang ditancapkan ke tanah. Besarnya arus radial tersebut dapat diukur dalam bentuk beda potensial pada suatu tempat tertentu di permukaan tanah, sehingga akan diperoleh informasi resistivitas batuan bawah permukaan (Hartantya, 2000).

Pengukuran muka air tanah metode geolistrik di daerah sekitar Aguobiri Southern Nigeria didapatkan bahwa air tanah masih bisa dikonsumsi dan belum tercemar oleh minyak (Egai, 2013).

Pengujian kualitas air diperlukan untuk mengetahui mutu air. Air memiliki sifat secara fisika, kimia dan biologi. Menurut Suripin (2002) karakteristik fisik yang mempengaruhi kualitas air ditentukan oleh warna, suhu, kekeruhan; karakteristik kimiawi air meliputi $\mathrm{pH}$, alkalinitas, dan kesadahan; dan karakteristik biologi berupa berbagai macam organisme hidup.

Data pengukuran muka air tanah dan pengujian kualitas air selanjutnya dikorelasikan untuk melihat hubungan antara kedua variabelnya.

Pemahaman dan informasi tentang air tanah melalui pengukuran muka air tanah perlu diinformasikan kepada masyarakat, termasuk kepada peserta didik di sekolah dengan menerapkan pembelajaran yang relevan. Peningkatan proses pembelajaran dapat dilakukan dengan suatu upaya strategi pembelajaran inovatif yaitu service learning (Andersen, 1998) dengan media berupa Lembar Kerja Peserta Didik (LKPD).

Service learning merupakan strategi pembelajaran yang mengintegrasi antara pengetahuan akademik dengan penyediaan kebutuhan masyarakat (Billig, 2003 dalam Cahyani et al, 2012). Service learning mencoba untuk menghubungkan peserta didik dengan tugas sekolah, yang intinya adalah untuk dipraktikkan di masyarakat.

Fakta-fakta mengenai air sering ditemukan dalam kehidupan sehari-hari. Berkaitan dengan service learning, permasalahan dalam LKPD diambil dari keseharian masyarakat dengan mengukur muka air tanah dengan geolistrik di sekitar perkebunan sawit.

Pembelajaran menggunakan strategi ini dapat lebih mudah diterapkan guru jika dalam proses pembelajarannya dilengkapi dengan bahan ajar berupa LKPD dengan menyisipkan fakta atau fenomena yang dapat menggali rasa ingin tahu peserta didik sehingga peserta didik dapat melakukan kegiatan penyelidikan dan pemecahan masalah.

\section{METODE PENELITIAN}

Penelitian sains yaitu dengan melakukan pengukuran kualitas air dan muka air tanah di sekitar perkebunan kelapa sawit. Kemudian hasil penelitian yang diperoleh diimplementasikan pada pembelajaran fisika untuk Kelas X jurusan Agribisnis Tanaman Perkebunan SMKN 7 Bengkulu Utara.

Jenis penelitian pembelajaran ini adalah penelitian dan pengembangan (R\&D). Produk yang disusun dalam penelitian ini adalah bahan ajar berbentuk LKPD Fisika Berbasis Service Learning materi hasil pengukuran muka air tanah dengan geolistrik di sekitar perkebunan sawit untuk menciptakan Reflective Thinking peserta didik.

Rancangan penelitian menggunakan langkah-langkah metode peneitian dan pengembangan (Research and Development/ R\&D) yang mengacu pada langkah-langkah model ADDIE.

Pengukuran kualitas air dan muka air tanah dilakukan di Dusun Simpang Beliben Desa Pondok Kelapa Bengkulu Tengah. Pengambilan sampel air sumur ditentukan sekitar titik yang diukur kedalaman muka air tanahnya. Terdapat 4 lokasi pengukuran yang telah ditentukan melalui survey.

Pengujian kualitas air sumur dilakukan di laboratorium Universitas Bengkulu. Variabel yang diuji secara fisika dan kimia adalah $\mathrm{pH}$, kadar besi (Fe) dan kekeruhan sampel. Pengujian $\mathrm{pH}$ dilakukan dengan menggunakan pH meter, pengujian kadar besi menggunakan spektrofotometer, dan pengujian kekeruhan menggunakan turbidimeter. Hasil uji sampel kemudian di analisis dengan mengacu pada daftar kualitas air untuk tiap peruntukan menurut peraturan pemerintah Republik Indonesia No.20 tahun 1990.

Pengukuran muka air tanah pada penelitian ini menggunakan alat Resistivity Meter tipe GE GL-4200, metode geolistrik dengan konfigurasi elektroda Wenner. Bagianbagian alat geolistrik terdiri dari Current transmitter, voltmeter, Amperemeter, Connection test, ADC, dan PC controller Current Transmitter. Alat pendukung dalam 
pengukuran muka air tanah yakni kompas, alat komunikasi dua arah, GPS, kamera, kabel 4 gulung, elektroda 4 buah dan pancang 20 buah.

Data yang diperlukan untuk pengukuran kualitas air tanah meliputi: jarak antara dua elektroda arus $\mathrm{AB}$, jarak antara dua elektroda potensial $\mathrm{MN}$, arus listrik (I), beda potensial $(\Delta \mathrm{V})$ yang berpandu pada stacking chart, kemudian diperoleh harga faktor koreksi geometri (K) dan nilai tahanan jenis $(\rho)$.

Pengukuran muka air tanah dilakukan dengan menginjeksikan arus listrik menggunakan 2 buah elektroda arus A dan B yang ditancapkan ke dalam tanah dengan jarak tertentu. Tegangan listrik yang terjadi di permukaan tanah diukur dengan menggunakan multimeter yang terhubung melalui 2 buah "elektroda tegangan" $\mathrm{M}$ dan $\mathrm{N}$ yang jaraknya lebih pendek dari jarak elektroda AB. Bila posisi jarak elektroda $A B$ diubah menjadi lebih besar maka tegangan listrik yang terjadi pada elektroda MN ikut berubah sesuai dengan informasi jenis batuan yang ikut terinjeksi arus listrik pada kedalaman yang lebih besar (Broto $\&$ Afifah, 2008).

Hasil akhir perhitungan dimasukkan ke dalam softwere RES2dinv untuk menggambarkan nilai resistivitas yang ada dalam permukaan bumi dalam bentuk peta kontur lapisan yang terkandung di dalamnya.

Subjek penelitian pembelajaran adalah siswa kelas X-ATP SMKN 7 Bengkulu Utara yang berjumlah 21 orang. Objek penelitian adalah LKPD Fisika berbasis service learning untuk meningkatkan reflective thinking peserta didik.

Model ADDIE menurut Mulyatiningsih (2016) meliputi 5 tahap yaitu tahap analisis (analysis), perancangan (design), pengembangan dan produksi (development and production), implementasi (implementation), dan evaluasi (evaluation).

Analisis validasi/kelayakan media dan respon peserta didik terhadap media dilakukan dengan menghitung rata-rata skor, rata-rata skor kemudian dikonversi menjadi skala empat yang tersaji dalam Tabel 1.
Tabel 1. Konversi skor ke Nilai

\begin{tabular}{|c|c|c|c|}
\hline No & \multicolumn{2}{|c|}{ Interval Skor } & Kategori \\
\hline 1 & $\mathrm{X} \geq \overline{\mathrm{X}}+1 . \mathrm{SB}_{\mathrm{x}}$ & $\mathrm{X} \geq 56$ & $\begin{array}{c}\text { Sangat } \\
\text { Baik }\end{array}$ \\
\hline 2 & $\overline{\mathrm{X}}+1 . \mathrm{SB}_{\mathrm{x}}>\mathrm{X} \geq \overline{\mathrm{X}}$ & $\begin{array}{c}56>\mathrm{X} \geq \\
48\end{array}$ & Baik \\
\hline 3 & $\overline{\mathrm{X}}>\mathrm{X} \geq \overline{\mathrm{X}}-1 . \mathrm{SB}_{\mathrm{x}}$ & $\begin{array}{c}48>\mathrm{X} \geq \\
40\end{array}$ & Cukup \\
\hline 4 & $\mathrm{X}<\overline{\mathrm{X}}-1 . \mathrm{SB}_{\mathrm{x}}$ & $\mathrm{X}<40$ & Kurang \\
\hline
\end{tabular}

Pengukuran kemampuan reflective thinking hasil pretest dan posttest dianalisis dengan gain score oleh Hake (1999) dalam Sutarno (2010).

$$
N_{\text {gain }}=\frac{\text { Skor }_{\text {Post }}-\text { Skor }_{\text {Pre }}}{\text { Skor }_{\text {Max }}-\text { Skor }_{\text {Pre }}}
$$

\section{HASIL DAN PEMBAHASAN}

Hasil pengujian kualitas air secara fisika dan kimia terhadap sampel air sumur oleh laboratorium ditunjukkan pada Tabel 2 berikut.

Tabel 2. Hasil analisa uji sampel

\begin{tabular}{|c|c|c|c|}
\hline \multirow{2}{*}{ Sampel } & \multicolumn{3}{|c|}{ Parameter Analisa } \\
\cline { 2 - 4 } & $\mathrm{pH}$ & Besi(mg/L) & Kekeruhan(NTU) \\
\hline Sampel 1 & 6,0 & 0,0021 & 54,16 \\
\hline Sampel 2 & 6,0 & 0,0022 & 37,12 \\
\hline Sampel 3 & 5,8 & 0,0021 & 35,65 \\
\hline Sampel 4 & 5,7 & 0,0011 & 19,02 \\
\hline
\end{tabular}

Analisis nilai $\mathrm{pH}$ pada sampel uji kualitas air menunjukkan sampel air bersifat asam yakni dengan $\mathrm{pH}$ sebesar 5,7-6. Menurut peraturan pemerintah Republik Indonesia No.20 tahun 1990 (terlampir), $\mathrm{pH}$ air dalam Gol A yang diperbolehkan adalah sebesar 6,5-8,5. Hal ini menunjukkan bahwa sampel air sumur dapat dikatakan tercemar dan tidak layak dikonsumsi.

Analisis kadar besi $(\mathrm{Fe})$ pada sampel uji kualitas air menunjukkan kandungan sebesar 0,0011-0,00022 $\mathrm{mg} / \mathrm{L}$. Menurut peraturan pemerintah Republik Indonesia No.20 tahun 1990, kandungan logam besi (Fe) dalam Gol A yang diperbolehkan adalah sebesar $0,3 \mathrm{mg} / \mathrm{L}$. Hal ini menunjukkan nilai yang sangat jauh dari batas yang diperbolehkan yakni 0,3, sehingga sampel air sumur dapat dikatakan tidak mengandung logam besi $(\mathrm{Fe})$.

Analisis tingkat kekeruhan pada sampel uji kualitas air menunjukkan rentang 19,02-54,16. Menurut peraturan pemerintah Republik Indonesia No.20 tahun 1990, kadar kekeruhan 
maksimum dalam Gol A yang diperbolehkan adalah sebesar 5 NTU. Hal ini menunjukkan nilai yang sangat jauh dari batas yang diperbolehkan yakni 5 NTU, sehingga sampel air sumur dapat dikatakan memiliki kadar kekeruhan yang sangat tinggi. Kekeruhan tersebut dapat disebabkan oleh padatan seperti pasir, endapan lumpur, tanah liat dan kandungan organiknya.

Data pengukuran muka air tanah dengan metode geolistrik setelah diolah untuk mendapatkan nilai tahanan jenis, selanjutnya dengan softwere Res2dinv. Hasil pengolahan data tersebut berupa distribusi resistivitas sebenarnya terhadap penampang melintang di bawah permukaan tanah. Berdasarkan penampang geolistrik ini dapat diketahui kedalaman dan struktur lapisan tanah yang divisualisasikan oleh warna tertentu.

Pada lintasan 1 hasil pengolahan data ditampilkan seperti gambar 1 berikut.

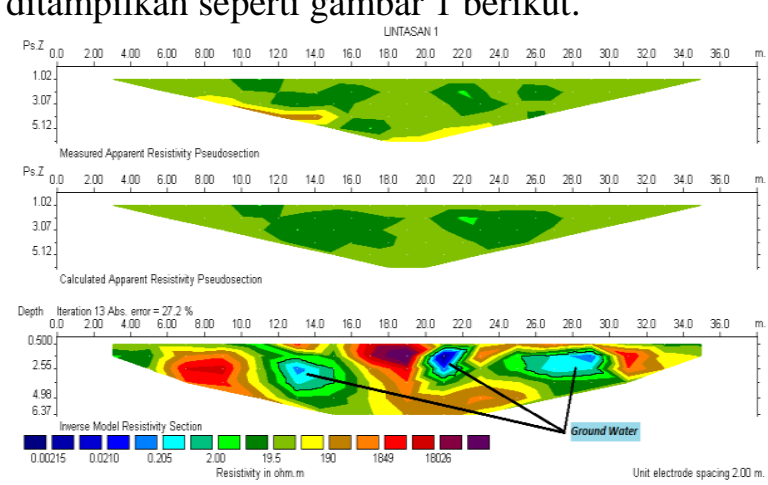

Gambar 1. Lapisan air tanah pada lintasan 1

Berdasarkan gambar 1 terlihat masih tersebarnya potensi air tanah, resistivitas air tanah ditunjukkan oleh warna biru yang berkisar antara 0,00215-0,206 $\Omega \mathrm{m}$ dengan ratarata kedalaman sebesar $1,967 \mathrm{~m}$.

Pada lintasan 2 hasil pengolahan data ditampilkan seperti gambar 2 berikut.

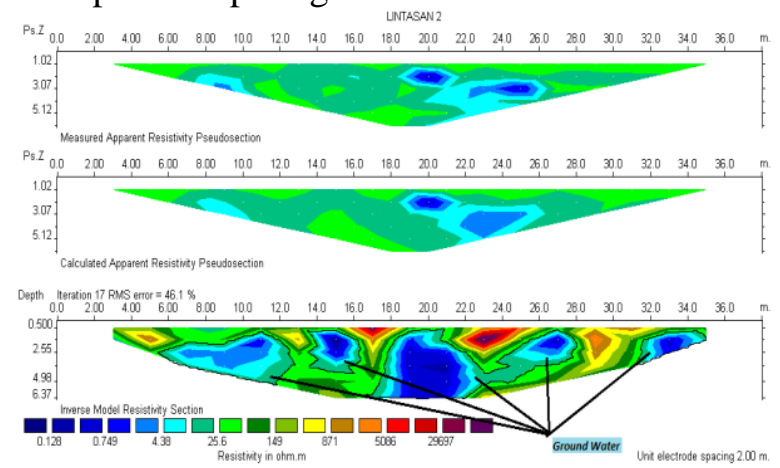

Gambar 2. Lapisan air tanah pada lintasan 2

Berdasarkan gambar 2 juga terlihat masih tersebarnya potensi air tanah, resistivitas air tanah ditunjukkan oleh warna biru yang berkisar antara $0,128-4,38 \Omega \mathrm{m}$ dengan rata-rata kedalaman sebesar $2,935 \mathrm{~m}$.

Pada lintasan 3 hasil pengolahan data ditampilkan seperti gambar 3 berikut.

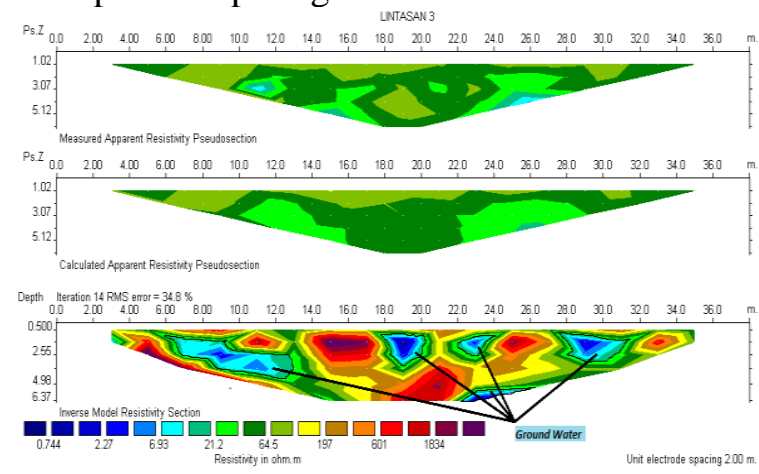

Gambar 3. Lapisan air tanah pada lintasan 3

Berdasarkan gambar 3 juga terlihat masih tersebarnya potensi air tanah, resistivitas air tanah ditunjukkan oleh warna biru yang berkisar antara $0,744-6,93 \Omega \mathrm{m}$ dengan ratarata kedalaman sebesar $2,240 \mathrm{~m}$.

Pada lintasan 4 hasil pengolahan data ditampilkan seperti gambar 4 berikut.

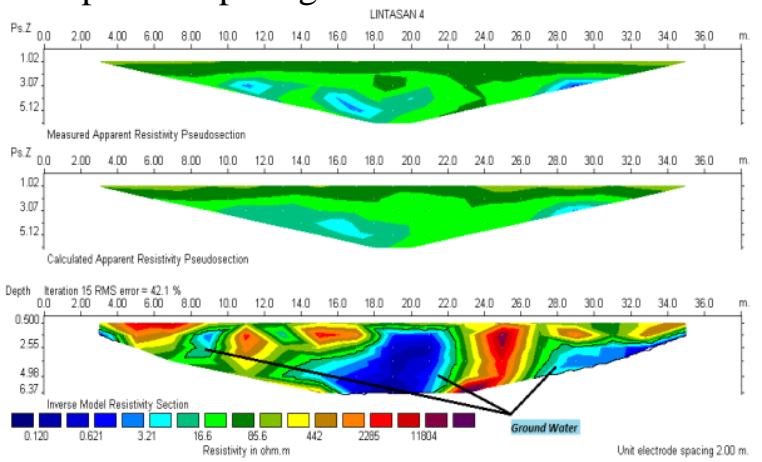

Gambar 4. Lapisan air tanah pada lintasan 4

Berdasarkan gambar 4 juga terlihat masih tersebarnya potensi air tanah, resistivitas air tanah ditunjukkan oleh warna biru yang berkisar antara 0,120-3,21 $\Omega \mathrm{m}$ dengan rata-rata kedalaman sebesar 2,679m. Keempat lintasan pengukuran diperoleh bahwa kedalaman muka air tanah tiap lintasan bervariasi.

Uji hipotesis terhadap hubungan kualitas air dengan kedalaman muka air tanah dilakukan dengan menggunakan korelasi product moment menunjukkan bahwa tidak terdapat kecenderungan hubungan antara $\mathrm{pH}$ dan kadar besi $(\mathrm{Fe})$ dengan muka air tanah.

Namun, terdapat kecenderungan hubungan terbalik antara kekeruhan dengan muka air tanah. Hubungan terbalik ini di definisikan bahwa semakin dekat/ pendek jarak muka air 
tanah dari permukaan tanah, maka tingkat kekeruhan semakin tinggi/ besar. Hal ini sejalan dengan penelitian Carlson, et al (2014), dari Stanford University dan University of Minnesota yang melakukan penelitian di Kabupaten Ketapang di pantai selatan Provinsi Kalimantan Barat, diungkapkan bahwa kualitas air secara signifikan terkikis dan risiko yang terkait dengan perkebunan kelapa sawit. Dampak yang terjadi, mulai dari menurunnya kualitas air dengan ditandai kekeruhan terjadi antara 40-713 NTU.

Hasil penelitian ditampilkan sebagai penunjang proses pembelajaran Fisika yakni pengembangan LKPD berbasis service learning materi Hukum Ohm penerapan pengukuran geolistrik di sekitar perkebunan sawit yang berorientasi pada pengembangan hasil belajar dengan desain ADDIE.

Skor kelayakan LKPD Fisika oleh dosen adalah sebesar 64,5 dan praktisi guru Fisika sebesar 69. Kedua skor termasuk ke dalam kategori "sangat baik" dan layak diujicobakan.

Peningkatan kemampuan hasil belajar menggunakan LKPD berbasis service learning diukur dengan menggunakan soal pretest dan posttest. Rata-rata nilai petest sebesar 49,05 dan nilai posttest sebesar 82,86 Berdasarkan ratarata nilai pretest dan posttest didapatkan peningkatan nilai hasil belajar sebesar 0,66. Nilai peningkatan 0,66 tersebut berada dalam rentang interval $0,30 \leq \mathrm{N}_{\text {-gain }} \leq 0,70$ dan termasuk dalam kategori "sedang".

Grafik hasil pretest dan posttest tersaji pada gambar 5 .

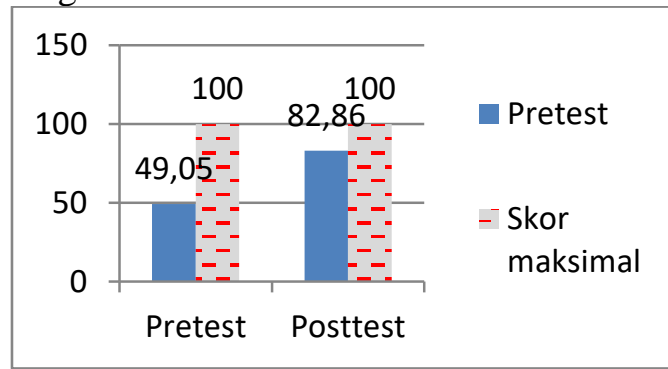

Gambar 5. Hasil pretest dan posttest

Berdasarkan perhitungan dari hasil pretest dan posttest, terdapat peningkatan hasil belajar setelah menggunakan bahan ajar LKPD Fisika.

Berdasarkan teori yang dikemukakan dalam Campus Compact National Center for Community Colleges (2002: 1) disebutkan bahwa service learning adalah metode pembelajaran yang mengkombinasikan community service dengan panduan akademik yang fokus pada berpikir kritis, berpikir refleksi, dan tanggung jawab. Teori tersebut sesuai dengan penelitian bahwa strategi service learning dapat meningkatkan hasil belajar ditinjau dari pretest dan posttest kemampuan hasil belajar.

\section{KESIMPULAN}

Berdasarkan penelitian yang telah dilakukan, dapat disimpulkan bahwa kualitas air ke empat sumur dari segi $\mathrm{pH}$ menunjukkan bahwa air bersifat asam rentang antara 5,7-6, kandungan besi $(\mathrm{Fe})$ rentang antara 0,0011-0,0022 mg/L menunjukkan bahwa air sumur tidak mengandung logam besi $(\mathrm{Fe})$, dan kekeruhan rentang antara 19,02-54,16 NTU yang berarti bahwa air sumur memliki kekeruhan yang sangat tinggi.

Kedalaman muka air tanah yang dilakukan dengan pengukuran geolistrik konfigurasi wenner menunjukkan bahwa lintasan 1 rata-rata kedalaman air tanah sebesar 1,967 m, lintasan 2 rata-rata kedalamannya sebesar 2,935 m, lintasan 3 rata-rata kedalamannya sebesar 2,240 $\mathrm{m}$, dan lintasan 3 rata-rata kedalamannya sebesar $2,679 \mathrm{~m}$.

Hubungan antara kualitas air dari segi kekeruhan dengan kedalaman muka air tanah memiliki hubungan yang "kuat". Sehingga dapat dikatakan ada kecenderungan hubungan terbalik antara kualitas air dan muka air tanah segi kekeruhan.

Pembelajaran dengan menggunaan LKPD Fisika berbasis service leaning materi Hukum Ohm dapat meningkatkan kemampuan hasil belajar ditinjau dari pretest dan posttest, diperoleh peningkatan sebesar 0,66 dengan kategori "sedang".

\section{DAFTAR PUSTAKA}

Andersen, Susan M. (1998). Service Learning: A National Strategy for Youth Development. The Communitarian Network's Education

Broto S \& Afifah S.R. (2008). Pengolahan Data Geolistrik dengan Metode Schlumberger. TEKNIK- Vol.29 No.2, ISSN 0852-1697

Cahyani, Vita A., Slamet S., \& Meti I. (2012). Pengaruh Penerapan Service Learning Terhadap Hasil Belajar Siswa Kelas XI 
SMA Negeri 1 Boyolali TP 2011/2012. No. 9. FKIP UNS.

Carlson, K.M, Lisa M Curran, Alexandra G. Ponette-González, Dessy Ratnasari, Ruspita, Neli Lisnawati, Yadi Purwanto, Kate A. Brauman, and Peter A. Raymond. (2014). Journal Ref: Influence of watershed-climate interactions on stream temperature, sediment yield, and metabolism along a land use intensity gradient in Indonesian Borneo. Journal of Geophysical Research: Biogeosciences.

DOI 10.1002/2013JG002516. 1110-1128

Egai, A.O. (2013). Geoelectric Characterization of Subsurface Crude Oil Leachate Plume in Aguobiri, Southern Nigeria. Research Journal in Engineering and Applied Science 2 (6) 427-433, ISSN: 2276-8467

Hartantya, E., 2000, Survai Elektromagnetik, UGM, Yogyakarta.

Mulyatiningsih, E. (2016). Pengembangan Model Pembelajaran. Diakses dari http://staff. uny. ac. id/sites/default/files/pengabdian/draendang-mulyatiningsihmpd/7cpengembangan-modelpembelajaran. pdf. pada September.

No, P. P. R. I. (20). Tahun 1990 Tentang: Pengendalian Pencemaran Air. Lembaran Negara Republik Indonesia.

Purnama, S., \& Sulaswono, B. (2007). Sistem Akuifer dan Potensi Airtanah Daerah Aliran Sungai (DAS) Opak.

Sandhyavitri, Ari. 2014. Kajian Upaya Pelestarian Sumber Daya Air Tanah Kemungkinan Akibat Pembangunan Kebun Kelapa Sawit di Provinsi Riau.

Suripin, 2002. Pelestarian Sumber Daya Tanah dan Air. Yogyakarta: Penerbit Andi 